\title{
The functional composition of the neophytic flora changes in response to environmental conditions along a rural-urban gradient
}

\author{
Janis Wolf', Dagmar Haase ${ }^{2,3}$, Ingolf Kühn ${ }^{4,5,6}$ \\ I Freie Universität Berlin, Institute of Biology, Königin-Luise-Str.1-3, 14195 Berlin, Germany 2 Humboldt \\ University Berlin, Geography Department, Rudower Chaussee 16, 12489 Berlin, Germany 3 Helmholtz Cen- \\ tre for Environmental Research - UFZ, Dept. Computational Landscape Ecology, Permoser Str. 15, 04318 \\ Leipzig, Germany 4 Helmholtz Centre for Environmental Research - UFZ, Dept. Community Ecology, Theo- \\ dor-Lieser-Str. 4, 06120 Halle, Germany 5 Martin Luther University Halle-Wittenberg, Geobotany \& Bota- \\ nical Garden, Am Kirchtor 1, 06108 Halle, Germany 6 German Centre for Integrative Biodiversity Research \\ (iDiv) Halle-Jena-Leipzig, Deutscher Platz 5e, 04103 Leipzig, Germany
}

Corresponding author: Janis Wolf(janis.wolf@fu-berlin.de)

Academic editor: Milan Chytrý| Received 9 August 2019 | Accepted 15 December 2019 | Published 15 January 2020

Citation: Wolf J, Haase D, Kühn I (2020) The functional composition of the neophytic flora changes in response to environmental conditions along a rural-urban gradient. NeoBiota 54: 23-47. https://doi.org/10.3897/ neobiota. 54.38898

\begin{abstract}
Compared to rural environments, cities are known to be extraordinarily rich in plant species. In particular, the proportion of alien plant species is higher in urban areas. This is attributed to specific urban conditions, which provide a large variety of habitats due to high geological heterogeneity. It can also be attributed to the role of cities as centres for plant introductions and the consequential increased propagule pressure. Neophytes, alien plant species introduced after the discovery of the Americas, appear to contribute especially strongly to the increased proportion of alien plants in cities. To investigate whether the plant traits of neophytes can be explained by environmental variables, we modelled the composition of their pollination types and growth forms as well as their diaspore weight and the onset of flowering in response to a selection of climatic, geological, land cover and traffic network variables with data from Germany. To test for a specific urban effect, we included their interactions with the area of urban land use.

In general, we found that climatic variables were the most important predictors for all traits. However, when considering interactions with urbanisation, non-climatic variables, which often were not significant as the main effect, remained in the final models. This points to an existing 'urban effect'. However, it is much smaller compared to the purely climatic effects. We conclude that interferences and alterations
\end{abstract}

Copyright Janis Wolf et al. This is an open access article distributed under the terms of the Creative Commons Attribution License (CC BY 4.0), which permits unrestricted use, distribution, and reproduction in any medium, provided the original author and source are credited. 
mainly related to urbanisation and human activity in general are responsible for the different ecological processes found in cities compared to rural areas. In addition, we argue that considering functional traits is an appropriate way to identify the ecological mechanisms related to urbanisation.

\section{Keywords}

Alien plants, cities, growth form, phenology, pollination, seed mass, traits, vector generalised linear model

\section{Introduction}

Next to climate and land-use change, biological invasions are regarded as one of the main drivers for the recent loss of biodiversity (Elton 1958, IPBES 2019). However, the arrival of new species in foreign regions does not necessarily lead to their successful establishment. In fact, some of these alien species rather benefit from changes in ecosystems (they are also called passengers of change) instead of causing them (also called drivers of change, Didham et al. 2005). In particular, those species successfully invading degraded ecosystems tend to be rather passengers of change (MacDougall and Turkington 2005). In turn, heavily disturbed habitats, such as urbanised areas, are the ones that are most strongly invaded (Kowarik 1990).

The increase in urban population (United Nations 2014) leads to an expansion of the urban built area at the cost of unsealed land (Douglas and James 2015). Therefore, urbanisation can be regarded as one of the main drivers of land-use change, often at the expense of natural ecosystems (Vitousek et al. 1997), and it will probably facilitate invasions in the future.

Due to their particular characteristics, cities differ from their surrounding nonurban areas by decreased mean annual air humidity and consequently drier soils (Bridgman et al. 1995), increased average annual temperature (Oke 1982, Bowler et al. 2010), and reduced wind speeds (Nowak et al. 2010). Further, the highly heterogeneous structure of urban areas offers a wider range of different habitats (Kühn et al. 2004). In addition, cities represent hotspots of human mobility and transportation which are considered important factors determining the number of invasive species (von der Lippe and Kowarik 2008, Jehlík et al. 2019, Seebens 2019).

In terms of cities also being hotspots for alien plant species, it is important to understand which plant traits benefit from, and which are disfavoured by urbanisation. Several studies have focussed on functional traits and whether they are either promoted or suppressed in cities. Their results seem to imply that plants that thrive in nutrient rich, alkaline soils as well as in warm and bright conditions are more successful in urban areas. Plants that prefer moist conditions are suppressed in cities (Williams et al. 2015). For example, in Germany, when compared to non-urban grid cells, urbanised grid cells had higher proportions of wind-pollinated plants, plants with scleromorphic leaves, and plants that are dispersed by animals. At the same time, these urban grid cells had lower proportions of insect-pollinated plants, plants with hygromorphic leaves, and plants dispersed by wind (Knapp et al. 2008b). 
The concept of the rural-urban gradient (Forman 2014) is widely used to highlight the variability of several environmental factors when transitioning from rural areas to the city centre. Kühn et al. (2017) tested for a potential urban effect on neophytes (i.e. species introduced after the discovery of the Americas, Pyšek et al. 2004), or more precisely, on their richness and proportion. Based on the assumption that the alien flora in cities differs from the alien non-urban flora, they expected changes in the responses of neophyte richness to environmental variables along the rural-urban gradient. If this holds true, they would speak of an existing urban effect. Their results, however, indicate that conditions that explain neophyte richness in cities are mostly the same as in rural environments but are more effective towards the urban end of the gradient (Kühn et al. 2017).

In this study, we aim to extend this approach and to test whether selected traits of neophytes are affected differently by environmental conditions along the rural-urban gradient. Firstly, working with traits allows to get beyond a purely taxonomic characterisation to a more functional approach (Kühn et al. 2006, McGill et al. 2006), secondly, we are not aware of many studies, that take a trait-based approach to urban flora (but see e.g. Knapp et al. 2008b, 2010, Fischer et al. 2013). In doing so, we hypothesise that the following traits will change in a rural-urban gradient: (1) pollination type, (2) growth form, (3) diaspore mass and (4) flowering phenology.

Pollination type describes the vector a plant employed for pollen transfer. We included this trait in the analysis because the main vectors, wind and insects, are known to differ between urban and rural landscapes (Connor et al. 2002, Nowak et al. 2010). We aim to test whether these differences also reflect variances in the proportion of insect-, wind- and self-pollinated neophytes in their response to environmental conditions. According to some studies, urbanisation favours wind pollination over biotic pollination (Lososová et al. 2006, Sodhi et al. 2008, Knapp et al. 2008a, 2010).

Growth form in this study is a combination of life form (Raunkiær 1934) and lifespan, a specification of lifetime and the number of possible generative reproductions. Therefore, growth form provides information on the duration of a plant's life cycle and whether it is woody or not. We analysed this trait because the different frequencies and intensities of disturbance in cities compared to rural areas might favour or disadvantage certain growth forms. Previous studies revealed that urbanisation tends to favour woody plants, i.e. trees and shrubs (Knapp et al. 2008a, Williams et al. 2015, but Chocholoušková and Pyšek 2003), therophytes/annuals (Sukopp and Werner 1983) as well as biennials (Chocholoušková and Pyšek 2003, Lososová et al. 2006), and disfavours geophytes (Williams et al. 2015, but Knapp et al. 2008a).

Diaspore mass is important, because large diaspores contain more resources and therefore have competitive advantages in the establishment of seedlings compared to small seeds (Westoby et al. 1996). Small diaspores, however, are more likely to be dispersed further and therefore are more likely to reach new appropriate habitats (Meyer and Carlson 2001). Hence, diaspore mass is linked to both processes of dispersal and establishment. It has been assumed that for every environment there is an optimal seed mass (Smith and Fretwell 1974). Urban environments should therefore also represent 
habitats ideally suited for a certain (rather lower) seed mass, because nutrients are usually sufficient but newly disturbed patches need to be colonised.

Flowering phenology refers to information about timing and range of flowering events and is of great importance for pollination and reproduction. Despite genetic determination, the beginning, end and the duration of flowering can be modified, mainly by climatic conditions (Trefflich in Klotz et al. 2002). Here, we test the hypothesis that flowering begins early in urban areas and in areas with higher temperatures and moderate precipitation.

In this study, we test whether there is an urban effect on the proportions of traits (pollination, growth form) or the average state (diaspore mass, phenology) of neophytes in the rural-urban gradient. To this end, we explain the functional composition of grid cells of the mapping scheme of the flora of Germany by different environmental variables. In addition, we added the interactions of each variable with the area of urban land-use to detect possible urban effects in comparison with the main effects of specific environmental variables.

\section{Data and methods}

\section{Floristic data}

The data for plant species occurrence was extracted from the latest version (2013) of the floristic mapping of Germany (NetPhyD and BfN 2013), which contains more than 14 million records of plant occurrences in Germany. Data is available at a grid resolution corresponding to 10' longitude and 6' latitude (c. $12 \mathrm{~km} \times 11 \mathrm{~km}$ ). Since fragments of grid cells in border regions or along coastlines have considerably fewer species, only grid cells equal to, or greater than, the size of the smallest full cell of Germany (c. $117 \mathrm{~km}^{2}$ ) were kept for analysis. As the survey efforts in different regions and the botanical knowledge of volunteers are heterogeneous (Manceur and Kühn 2014), we followed Kühn et al. (2006) in only including grid cells with at least 45 out of 50 control species (those widely spread which should be present in each well-mapped grid cell), resulting in $\mathrm{n}=2599$ grid cells.

Only naturalised occurrences of neophytes from 1950 onwards were considered. Data on floristic status was retrieved from BiolFlor (Klotz et al. 2002). In total, 497 different neophyte species were included in the analysis, varying widely in frequency of occurrence (Suppl. material 1, Table S1).

\section{Trait data}

Data on the four traits (pollination, growth form, diaspore mass, flowering phenology) was also retrieved from BiolFlor (Klotz et al. 2002) and merged with the plant occurrence data based on species names or synonyms. The categorial traits pollination type and growth form comprise several trait states (Table 1). For some species, multiple 
Table I. Description, abbreviation and source of the traits and response variables used in the analyses.

\begin{tabular}{|c|c|c|c|c|}
\hline Trait & Description & Response var. & Abbreviation & Source \\
\hline \multirow[t]{4}{*}{$\begin{array}{l}\text { Pollination } \\
\text { type }\end{array}$} & \multirow{4}{*}{$\begin{array}{c}\text { Type of pollen transfer to the stigma. Either } \\
\text { abiotic or biotic. Only the three most common } \\
\text { types were considered and only those which were } \\
\text { assigned as always, often or the rule for each plant } \\
\text { in BiolFlor. }\end{array}$} & $\begin{array}{c}\text { Insect pollination } \\
\text { (entomophily) }\end{array}$ & $\mathrm{i}$ & \multirow[t]{4}{*}{$\begin{array}{l}\text { Durka in Klotz et al. } \\
\text { (2002) }\end{array}$} \\
\hline & & $\begin{array}{l}\text { Wind pollination } \\
\text { (anemophily) }\end{array}$ & $\mathrm{w}$ & \\
\hline & & Self-pollination (autogamy) & $s$ & \\
\hline & & Multiple & $\mathrm{m}$ & \\
\hline \multirow{5}{*}{$\begin{array}{l}\text { Growth } \\
\text { form }\end{array}$} & \multirow[t]{5}{*}{ Trait combining lifespan and life form. } & Annuals & an & \multirow{5}{*}{$\begin{array}{l}\text { Krumbiegel in Klotz et } \\
\text { al. (2002) }\end{array}$} \\
\hline & & Biennials & bn & \\
\hline & & Herbaceous perennial & hp & \\
\hline & & Woody plants & wd & \\
\hline & & Multiple & $\mathrm{mu}$ & \\
\hline $\begin{array}{l}\text { Diaspore } \\
\text { mass }\end{array}$ & $\begin{array}{c}\text { Mean mass of diaspore (germinal plus any } \\
\text { dispersal-assisting tissue). }\end{array}$ & mean $(\log ($ diaspore mass $))$ & - & $\begin{array}{l}\text { Otto in Klotz et al. } \\
\qquad(2002)\end{array}$ \\
\hline $\begin{array}{l}\text { Flowering } \\
\text { phenology }\end{array}$ & $\begin{array}{l}\text { Mean month at which neophytes of a grid cell } \\
\text { begin to flower. }\end{array}$ & $\begin{array}{c}\text { mean(beginning month of } \\
\text { flowering) }\end{array}$ & mean(BFM) & $\begin{array}{l}\text { Trefflich in Klotz et al. } \\
(2002)\end{array}$ \\
\hline
\end{tabular}

pollination types were recorded or the state of life span can have several states. In these cases, an additional state called 'multiple' was introduced.

\section{Environmental data}

Data for model prediction is comprised of data on climate, geology, land cover and traffic network. A total of 19 initial environmental predictors (see Table 2) were selected based on physiological principles known to be related to species richness in general, and alien species richness in particular (Kühn et al. 2017).

\section{Statistical analysis}

\section{Model specification and simplification}

All environmental predictors were centred to zero mean and unit standard deviation. Collinearity between the environmental predictors was assessed, but none of the pairs of predictors showed high collinearity ( $\mid$ Kendall's $\tau \mid>0.7$; Dormann et al. 2013).

One problem with compositional data is that the proportions are not independent of each other: if one proportion increases, at least one of the others must decrease and vice versa. This is called the unit-sum-constraint and can be obviated by using the logarithms of ratios (log-ratios) instead of the observed proportions (Aitchison 1986, Billheimer et al. 2001, Kühn et al. 2006). While, mathematically, the choice of denominator and numerator for the log-ratios is arbitrary and does not impair the results (Aitchison 1986), for the purpose of interpretation, the choice depends on the respective ecological interest. Therefore, to model the proportions of the states of pollination type and growth form in response to the environmental variables, we used a vector generalised linear model (VGLM; Yee 2015) with a multinomial distribution family based on log-ratios (Lososová et al. 2012, Menzel et al. 2016). This approach 
Table 2. Environmental data and sources used for analysis of the response variables. Variables are known to be related to species richness in general and alien species richness in particular. We provide units and variable range for linear but not for quadratic predictors. In such cases, the units (and $\mathrm{min} / \mathrm{max}$ values) do not make sense and the transformation was performed to account for non-linear relationships.

\begin{tabular}{|c|c|c|c|c|}
\hline Variable & Description of variable & Units & $\begin{array}{l}\text { Variable range } \\
(\min -\mathbf{m a x})\end{array}$ & Source \\
\hline TimpJul & Average July temperature & ${ }^{\circ} \mathrm{C}$ & $12.8-19.8$ & Fronzek et al. (2012), \\
\hline$T m p J u l^{2}$ & Squared average July temperature & & & observation period $1961-2000$ \\
\hline TimpAnnualRange & $\begin{array}{c}\text { Annual temperature range, i.e. average difference } \\
\text { between January and July temperature }\end{array}$ & ${ }^{\circ} \mathrm{C}$ & $21.5-29.1$ & \\
\hline PrecipitationSummer & $\begin{array}{c}\text { Average summer precipitation (June, July, } \\
\text { August) }\end{array}$ & $\mathrm{mm}$ & $168-494$ & \\
\hline PrecipitationSummer $^{2}$ & Squared average summer precipitation & & & \\
\hline WindSpeed & Average wind speed & $\mathrm{m} / \mathrm{s}$ & $1.9-5.6$ & \\
\hline \#GeoPatch & Number of geological patches & & $1-51$ & Bundesanstalt für \\
\hline \#GeoType & Number of geological types & & $1-24$ & Geowissenschaften und \\
\hline LoessArea & Area covered by loess & $\mathrm{km}^{2}$ & $0-114.1$ & Rohstoffe (1993) \\
\hline SandArea & Area covered by sand & $\mathrm{km}^{2}$ & $0-135.2$ & \\
\hline LimestoneArea & Area covered by limestone & $\mathrm{km}^{2}$ & $0-135.4$ & \\
\hline \#LcPatch & Number of land cover patches & & $26-353$ & LBM_DE2012 - Bundesamt \\
\hline \#LcType & Number of land cover types & & $5-22$ & für Kartographie und Geodäsie \\
\hline ForestArea & Forest area & $\mathrm{km}^{2}$ & $0-131.5$ & $(2012)$ \\
\hline AgriculturalArea & Agricultural area & $\mathrm{km}^{2}$ & $0.5-124.7$ & \\
\hline UrbanArea & Urbanised area & $\mathrm{km}^{2}$ & $0-79.7$ & \\
\hline RiverArea & River area & $\mathrm{km}^{2}$ & $0-8.5$ & \\
\hline RoadLength & Total length of roads & $\mathrm{km}$ & $0.2-29.2$ & Open Street Map Project and \\
\hline RailwayLength & Total length of railways & $\mathrm{km}$ & $0-6.1$ & MapCruzin (undated) \\
\hline
\end{tabular}

accounts for the above-described problem of the unit-sum-constraint. For both categorical traits, 'multiple' was used as the denominator. For simplicity, the ratios of the unambiguously assignable trait states over 'multiple' hereafter are simply called 'ratios'. Diaspore mass and flowering phenology are metric. Therefore, generalised linear models (GLM) were fitted.

In order to detect a potential 'urban effect', a different model was fitted to each of these four traits (either VGLM or GLM) with all the environmental variables (except wind speed, see below) as initial predictors plus the interactions of each variable with the area of urban land cover (UrbanArea; hereafter called 'urbanised area'). In addition, the initial models for pollination type, diaspore mass and flowering phenology also included the variable of average wind speed and its interaction with the urbanised area. The model simplification process for the generalised linear models (GLM) and vector generalised linear models (VGLM) followed the recommendations of Crawley (2012) by implementing a backward selection based on error probabilities such that a predictor was significant for at least one log-ratio.

\section{Spatial autocorrelation}

To test for spatial independency of the residuals, Moran's Index (the autocorrelation equivalent of Pearson's correlation coefficient) was calculated using the R package ncf by Bjørnstad (2013). All initially fitted models (VGLM and GLM) showed highly spa- 
tially autocorrelated residuals (Moran's $I>0.04[p<0.05]$ ) up to a distance of 10 grid cells and therefore were not suitable for drawing robust conclusions.

To account for spatial autocorrelation, a method called the 'residuals autocovariate approach' was applied (Crase et al. 2012). As this approach calculates an autocovariate from the residuals (hereafter called 'residual autocovariate', $R A C$ ) instead of deriving it from the response variables themselves, it does not suffer from biased parameter estimates that were reported by Dormann (2007). For VGLMs, the number of $R A C s$ equals the number of log-ratios that are included in the model. In generalised linear models with only one response variable, only one residual autocovariate was calculated.

During each step of model simplification (see above), new RACs for the updated model were calculated and the process was repeated until the final model was selected. This procedure ensured that the most accurate autocorrelation structure was utilised at every step. The residual autocorrelation could be reduced to a satisfying level for all final models.

\section{Model evaluation}

To evaluate the model fits, their explained deviance $D^{2}$ was calculated (Guisan and Zimmermann 2000). To assess whether the $D^{2}$ of the final models $\left(D_{t o}^{2}\right)$ is mainly due to the environmental variables or the residual autocovariates, it was partitioned into the deviance explained by the environmental-only $\left(D_{e n v}^{2}\right)$ and by the residual autocovariate-only model $\left(D_{r a c}^{2}\right.$; Borcard et al. 1992). We never observed an overlap between the two groups.

\section{Software}

All statistical analysis was performed with the software R, version 3.4.1 (R Core Team 2017). The following packages were used, mainly for data processing purposes: raster (Hijmans et al. 2016), sp (Pebesma et al. 2017), corrgram (Wright 2017), and VGAM (Yee 2017).

To calculate area and length per grid cell, it was necessary to indicate the intersections of the land-cover data and traffic network systems with the lattice used for the floristic mapping. This was performed with the geographical information systems (GIS) ArcGIS 10.5 (ESRI 2016) and QGIS 2.18 (QGIS Development Team 2015).

\section{Results}

While trait information on pollination, growth form and flowering phenology was available for the majority of species, information on seed mass was scarcer (for details see Table 3). The most common pollination type was insect pollination and most species were either annuals or herbaceous perennials (Figure 1). In the following, we will focus on the most pertinent results of the statistical analyses (Tables 4-6). 
Table 3. Number of neophytes per trait and trait state used for analysis. For minimum, maximum, median and/or mean values see Suppl. material 1, Table S2.

\begin{tabular}{lccc}
\hline \multicolumn{1}{c}{ Trait } & Trait state & \multicolumn{2}{c}{ Number of species } \\
& & per trait state & total \\
\hline Pollination type & Insect pollination & 262 & 438 \\
& Wind pollination & 69 & \\
& Self-pollination & 82 & \\
Growth form & Multiple & 25 & 492 \\
& Annuals & 157 & \\
& Biennials & 32 & \\
& Herbaceous perennial & 193 & \\
Diaspore mass & Woody plants & 74 & \\
Flowering phenology & Multiple & 36 & 482 \\
\hline
\end{tabular}
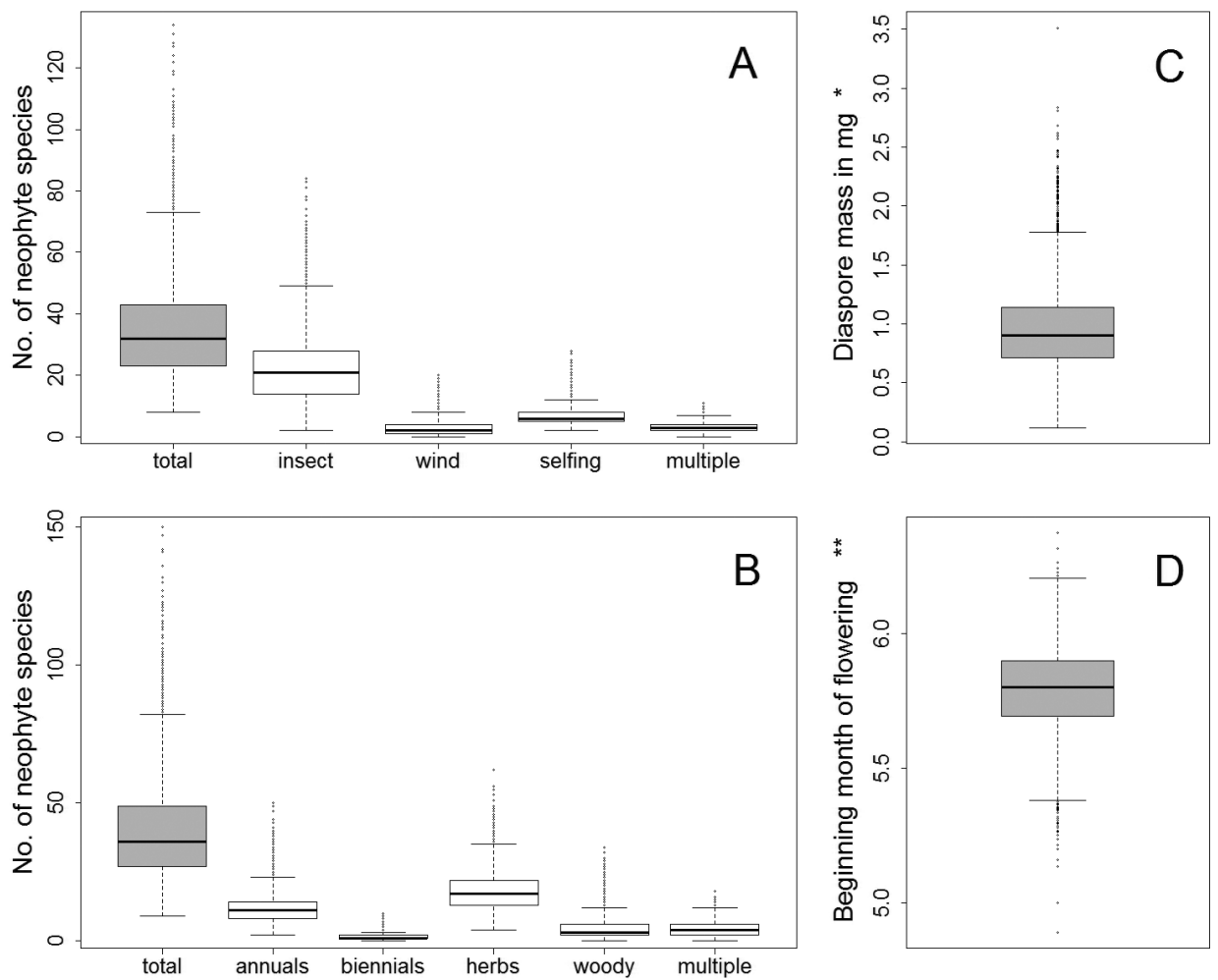

Figure I. Overview of trait states of neophytes across the 2599 grid cells of Germany A pollination type $\mathbf{B}$ growth form $\mathbf{C}$ diaspore mass (*back-transformed mean of $\log$ transformation) and $\mathbf{D}$ time (in months) at which neophytes begin to flower (**mean/grid cell). Bold black lines represent medians, boxes $25-75 \%$ interquartiles, whiskers samples with less than 1.5 times of the interquartile range and dots are outliers. For detailed values see Suppl. material 1, Table S2. 


\section{Pollination type}

The explanatory power of the model was quite good, though only half of the variation explained refers to environmental information (Table 4). Wind speed had the strongest negative effect on the relative ratio of insect-pollinated neophytes (Table 4A). Geological characteristics and land cover features were of additional, but much less, importance. We found a significant interaction: in more urbanised areas insect pollination decreases with low July temperatures and increases again with temperatures rising higher than the mean for July.

The $\log$-ratio of wind pollination $(\log [\mathrm{w} / \mathrm{m}])$ had by far the highest number of significant predictors of all log-ratios in the model (Table 4B). In turn, climatic variables had the absolute largest parameter estimates by far. For July temperatures, there seems to be an optimum pollination ratio around average temperatures. Very low temperatures lead to a strong decrease, and high temperatures to a moderate decrease of wind-pollinated species. Further results indicate that highly urbanised

Table 4. Estimates of modelling the log ratios of (A) insect pollination, (B) wind pollination, and (C) selfing over multiple pollination types. For modelling, a vector generalised linear model (VGLM) was used that included a multinomial distribution family and residual autocovariates (RAC) to account for spatial autocorrelation (SAC). $D_{t o t}^{2}$ - deviance of final model; $D_{e n v}^{2}$ - deviance of environmental-only model; $D_{r a c}^{2}$ - deviance of residual autocovariate-only model. Bold numbers indicate significant values. Asterisks represent error probabilities: $\circ 0.1>p \leq .05$; $^{*} .05>p \leq .01 ;{ }^{* *} .01>p \leq .001 ;^{* * *} p<.001$. For abbreviations of predictors see Table 2 .

\begin{tabular}{|c|c|c|c|}
\hline Predictor & (A) $\log (\mathrm{i} / \mathrm{m})$ & (B) $\log (w / m)$ & (C) $\log (\mathrm{s} / \mathrm{m})$ \\
\hline Intercept & $+1.791^{* * *}$ & $-0.482 * * *$ & $+0.746^{* * *}$ \\
\hline UrbanArea & $+0.027^{\circ}$ & $+0.097^{* * *}$ & +0.010 \\
\hline TmpAnnualRange & $+0.038^{\circ}$ & $+0.277^{* * *}$ & +0.003 \\
\hline TmpJul & -0.245 & $+1.189 *$ & -0.653 \\
\hline$T m p J u l^{2}$ & +0.072 & $-1.172 *$ & +0.679 \\
\hline PrecipitationSummer & -0.021 & $-1.114^{* * *}$ & $+0.626^{* * *}$ \\
\hline PrecipitationSummer $^{2}$ & +0.057 & $+1.116^{* * *}$ & $-0.491^{* * *}$ \\
\hline WindSpeed & $-0.150 * * *$ & $-0.128 * * *$ & -0.021 \\
\hline \#GeoPatch & $-0.027 *$ & -0.008 & -0.022 \\
\hline LoessArea & $+0.035^{* *}$ & $+0.035 *$ & +0.013 \\
\hline SandArea & $-0.048 * * *$ & $+0.038^{\circ}$ & -0.022 \\
\hline \#LcType & -0.004 & $+0.050 *$ & +0.002 \\
\hline \#LcPatch & +0.007 & $-0.021 * *$ & $+0.055^{* * *}$ \\
\hline AgriculturalArea & $+0.062 * * *$ & +0.020 & -0.001 \\
\hline RiverArea & +0.013 & $+0.085^{* * *}$ & $+0.029 *$ \\
\hline UrbanArea:TmpJul & $+0.044^{* *}$ & $+0.057^{* *}$ & $+0.051^{* *}$ \\
\hline UrbanArea: WindSpeed & +0.020 & $+0.067^{* * *}$ & -0.003 \\
\hline UrbanArea:SandArea & -0.008 & $-0.051^{* *}$ & -0.013 \\
\hline$R A C 1$ & $+9.565^{* * *}$ & +0.373 & -0.079 \\
\hline$R A C 2$ & +0.013 & $+8.942 * * *$ & +0.024 \\
\hline$R A C 3$ & -0.254 & +0.026 & $+9.626 * * *$ \\
\hline$D_{t o t}^{2}$ & & 0.61 & \\
\hline$D_{e n v}^{2}$ & & 0.29 & \\
\hline$D_{r a c}^{2}$ & & 0.30 & \\
\hline
\end{tabular}


areas seemingly harbour more wind-pollinated neophytes. It is also noteworthy that the ratio of wind pollination was the only log-ratio in the model with more than one significant interaction. In more urbanised areas, the ratio of wind pollinated neophytes increases even more with intermediate to high July temperatures and decreases with low July temperatures. Further, the ratio of anemophily decreased less in more urbanised areas with higher wind speeds than in non-urban areas. While the effect of sandy areas was not significant in non-urban areas, it had a negative influence in more urbanised areas.

The ratio of self-pollinators was mostly related to climatic variables, and most strongly to the linear and cubic terms of summer precipitation with an optimum around the average amount of precipitation (Table 4C). July temperature appeared to be the only variable that significantly interacted with the urbanised area. With temperatures higher than the mean, selfing is slightly more frequent in more urbanised areas. With lower temperatures, the frequency of selfing slightly decreases in more urbanised areas.

\section{Growth form}

The explained deviance of growth form was comparable to that of pollination (Table 5). The ratio of annual neophytes decreased with a wider annual temperature range and to a lesser degree with a larger number of land cover patches per grid cell (Table 5A). It increased with higher July temperatures and a larger river area. Agricultural area had a significant and negatively related interaction with urbanised area, however, it was not significant as a main effect.

The most important positively related variable explaining the ratio of biennials was the main effect of urbanised area (Table 5B). Most important in general was precipitation (linear and cubic forms). Similar to annuals, the quadratic effect of summer precipitation revealed a minimum ratio of biennials around average amounts of precipitation. Again, land cover and geological predictors had minor effects.

Except for the quadratic effect of summer precipitation, the ratio of herbaceous perennials was explained only by negatively related variables: annual temperature range, July temperature, urbanised area and river area (Table 5C). Most of the land cover and geological predictors were insignificant.

The ratio of woody plants increased with a wider annual temperature range and decreased with increasing average July temperatures (Table 5D). Again, as summer precipitation was negatively related and squared summer precipitation was positively related, the ratio of woody species first decreased with low to intermediate amounts of precipitation and increased with intermediate to high precipitation in summer. Again, non-climatic predictors were less important and even the many interactions they entailed were weak, even if significant. 
Table 5. Estimates of modelling the log ratios of (A) annuals, (B) biennials, (C) perennial herbs, and (D) woody plants over multiple types. A vector generalised linear model (VGLM) was used that included a multinomial distribution family and residual autocovariates (RAC) to account for spatial autocorrelation (SAC). $D_{t o t}^{2}$ - deviance of final model; $D_{e n v}^{2}$ - deviance of environmental-only model; $D^{2}{ }_{n a c}$ - deviance of residual autocovariate-only model. Bold numbers indicate significant values. Asterisks represent error probabilities: $\circ 0.1>p \leq .05 ;^{*} .05>p \leq .01 ;^{* *} .01>p \leq .001$; $^{* * *} p<.001$. For abbreviations of predictors see Table 2 .

\begin{tabular}{|c|c|c|c|c|c|}
\hline Predictor & (A) $\log (\mathrm{an} / \mathrm{mu})$ & (B) $\log (\mathbf{b n} / \mathrm{mu})$ & (C) $\log (\mathrm{hp} / \mathrm{mu})$ & (D) $\log (w d / m$ & $\mathrm{mu})$ \\
\hline Intercept & $0.979 * * *$ & $-1.055^{* * *}$ & $+1.443^{* * *}$ & -0.040 & $* *$ \\
\hline UrbanArea & -0.034 & $+0.083 *$ & $-0.053 *$ & +0.038 & \\
\hline TimpAnnualRange & $-0.106^{* * *}$ & $+0.058 *$ & $-0.071^{* * *}$ & +0.129 & $* * *$ \\
\hline TmpJul & $0.070^{* * *}$ & $-0.051^{\circ}$ & $-0.062^{* * *}$ & -0.068 & $* * *$ \\
\hline PrecipitationSummer & $-0.651^{* * *}$ & $-1.009^{* * *}$ & $-0.253 *$ & -1.442 & $* * *$ \\
\hline PrecipitationSummer $^{2}$ & $0.546 * * *$ & $+0.911^{* * *}$ & $+0.232 *$ & +0.992 & $* * *$ \\
\hline \#GeoPatch & 0.018 & -0.009 & +0.010 & +0.037 & $* *$ \\
\hline LoessArea & -0.015 & +0.009 & -0.001 & +0.035 & $* *$ \\
\hline SandArea & 0.012 & $-0.056 * *$ & -0.014 & +0.016 & \\
\hline LimestoneArea & -0.011 & $-0.037^{\circ}$ & +0.004 & -0.050 & $* *$ \\
\hline \#LcType & $-0.046^{* *}$ & $+0.063 * *$ & +0.013 & +0.025 & \\
\hline AgiculturalArea & 0.002 & $-0.095^{* * *}$ & +0.010 & -0.009 & \\
\hline RiverArea & $0.020 *$ & $-0.046 * *$ & $-0.020 *$ & -0.009 & \\
\hline RoadLength & -0.035 & $-0.154^{* * *}$ & -0.027 & -0.095 & $* * *$ \\
\hline UrbanArea:PrecipitationSummer & -0.014 & -0.003 & -0.016 & +0.042 & $* *$ \\
\hline UrbanArea:\#GeoPatch & -0.011 & -0.001 & -0.007 & -0.025 & * \\
\hline UrbanArea:LimestoneArea & 0.023 & -0.002 & +0.003 & +0.061 & $* *$ \\
\hline UrbanArea:AgiculturalArea & $-0.019 *$ & +0.002 & $-0.019 *$ & -0.019 & $\stackrel{\circ}{\circ}$ \\
\hline$R A C 1$ & $9.646^{* * *}$ & -0.060 & -0.032 & -0.248 & \\
\hline$R A C 2$ & -0.165 & $+8.870^{* * *}$ & -0.100 & +0.010 & \\
\hline$R A C 3$ & -0.120 & +0.073 & $+9.439 *$ & -0.440 & \\
\hline$R A C 4$ & 0.127 & +0.036 & +0.150 & +9.750 & $* * *$ \\
\hline$D_{\text {tot }}^{2}$ & \multicolumn{5}{|c|}{0.63} \\
\hline$D_{e n v}^{2}$ & \multicolumn{5}{|c|}{0.30} \\
\hline$D_{r a c}^{2}$ & \multicolumn{5}{|c|}{0.30} \\
\hline
\end{tabular}

\section{Diaspore mass}

The explained deviance of diaspore mass was quite high, but almost twice as much deviance was explained by the autocorrelation structure than was by environmental factors (Table 6A). The most important predictor, again, was summer precipitation. It was quadratically related with diaspore mass and furthermore was significant as quadratic interaction with urbanised area. Hence, minimum masses can be detected just above mean amounts of precipitation; lower and higher amounts of precipitation predict heavier diaspores. The interaction indicates that this main effect of precipitation on diaspore mass is strongly amplified in more urbanised areas. Once again, the nonclimatic variables were less important. 
Table 6. Estimates of modelling (A) the mean log-transformed diaspore mass per grid cell and (B) untransformed beginning-month of flowering. Generalised linear models (GLM) were fitted including residual autocovariates (RAC) to account for spatial autocorrelation (SAC). $D_{t o t}^{2}-$ deviance of final model; $D_{e n v}^{2}$ - deviance of environmental-only model; $D_{r a c}^{2}$ - deviance of residual autocovariate-only model. Bold numbers indicate significant values. Asterisks represent error probabilities: $\circ 0.1>p \leq .05$; $^{*} .05>p \leq .01$; ** $.01>p \leq .001{ }^{* * *} p<.001$. For abbreviations of predictors, see Table 2.

\begin{tabular}{|c|c|c|}
\hline Predictor & (A) Diaspore mass & (B) Onset of flowering \\
\hline Intercept & $+0.115^{* * *}$ & $+5.793 * * *$ \\
\hline UrbanArea & $-0.046 * * *$ & -0.007 \\
\hline TimpAnnualRange & -0.002 & $-0.013 * * *$ \\
\hline TimpJul & $+0.270^{\circ}$ & $+0.021 * * *$ \\
\hline$T m p J u l^{2}$ & $-0.013^{* *}$ & \\
\hline PrecipitationSummer & $-0.398 * * *$ & $+0.123^{* * *}$ \\
\hline PrecipitationSummer $^{2}$ & $+0.308^{* * *}$ & $-0.132 * * *$ \\
\hline WindSpeed & $-0.214^{* * *}$ & $-0.027^{* * *}$ \\
\hline \#GeoPatch & $-0.026 * * *$ & +0.003 \\
\hline SandArea & $-0.018^{* * *}$ & +0.003 \\
\hline LoessArea & $+0.031^{* * *}$ & \\
\hline LimestoneArea & $-0.018^{* * *}$ & \\
\hline \#LcType & & $0.014^{* * *}$ \\
\hline \#LcPatch & $+0.028^{* * *}$ & \\
\hline ForestArea & & $-0.028^{* * *}$ \\
\hline AgiculturalArea & $+0.090^{* * *}$ & $-0.032 * * *$ \\
\hline RiverArea & & $+0.017^{* * *}$ \\
\hline RoadLength & $+0.020 *$ & $+0.021 * * *$ \\
\hline UrbanArea:TmpAnnualRange & $-0.039 * * *$ & \\
\hline UrbanArea:TmpJul & $+0.026 * * *$ & $+0.010^{* * *}$ \\
\hline UrbanArea:PrecipitationSummer & $-0.217^{* * *}$ & \\
\hline UrbanArea:PrecipitationSummer ${ }^{2}$ & $+0.225^{* * *}$ & \\
\hline UrbanArea:\#GeoPatch & & $-0.009 * *$ \\
\hline UrbanArea:SandArea & & $-0.009 * * *$ \\
\hline UrbanArea:LoessArea & $-0.014^{* *}$ & \\
\hline UrbanArea:LimestoneArea & $-0.029 * * *$ & \\
\hline UrbanArea:ForestArea & & $-0.018 * * *$ \\
\hline UrbanArea:AgiculturalArea & & $-0.016 * * *$ \\
\hline UrbanArea:RoadLength & & $-0.018^{* * *}$ \\
\hline$R A C$ & $+9.842^{* * *}$ & $+9.947^{* * *}$ \\
\hline$D_{t o t}^{2}$ & 0.66 & 0.51 \\
\hline$D_{e n v}^{2}$ & 0.21 & 0.16 \\
\hline$D_{r a c}^{2}$ & 0.39 & 0.33 \\
\hline
\end{tabular}

\section{Flowering phenology}

The explained deviance of flowering phenology was lower than for the other traits with even less explanatory power of the environmental variables (Table 6B). As in the previous traits, summer precipitation was quadratically related to flowering phenology with an optimal amount of precipitation around the average. While urbanised area was not a significant variable itself, six significant interactions with urbanised area remained in the final model. The significant interactions were usually much weaker than their main effects. 


\section{Discussion}

We analysed trait compositions of alien plant species assemblages with respect to their pollination type, growth form, diaspore mass and flowering phenology at an intermediate spatial scale (i.e. extent is the area of Germany and c. $130 \mathrm{~km}^{2}$ resolution). We tested whether their composition (for categorical traits) or mean traits values (for metric traits), respectively, are linked to the geographical variation of different environmental conditions, specifically in the rural-urban gradient. Despite the coarse resolution of our input data and rather small shifts in the composition of pollination types, growth forms, mass of diaspores and flowering phenology, the results revealed distinct responses to environmental factors (Tables 4-6). Other studies, e. g. Williams et al. (2015), also analysed a suite of other plant characteristics. However, they chose many niche related features that are not functional traits in the strict sense of the term, but are instead environmental associations (following the concept of Garnier et al. 2017) or compound and derived features such as Grime's CSR strategy, both of which we avoided in order to focus our study. We did not aim, however, to cover the full spectrum of traits available.

\section{Pollination type}

In most other studies, pollination did not differ between urban and non-urban environments (see studies reviewed in Williams et al. 2015). In these studies, pollination was shown to be mainly affected by climatic conditions. While wind pollination benefits from low to moderate wind speed, low humidity and infrequent precipitation, insect pollination is promoted by low wind speed, higher humidity rates and infrequent to common rainfall (Kühn et al. 2006). Obviously, insect pollination is limited by insect abundance. However, there is no sufficient data for study available at an appropriate resolution and extent. Still, wind speed across Germany is around 100 times faster than necessary to dispatch pollen from anthers (Kühn et al. 2006, based on data from Whitehead 1968). Therefore, wind is not a limiting factor and hence we conclude that insect activity declining with increasing wind speed is responsible for the observed pattern (c.f. Digby 1958, van Swaay et al. 2002). The higher ratio of anemophily is also hypothesised to be related to phylogeny and correlates, for example, with a high proportion of Poaceae and Chenopodiaceae (which are mainly wind-pollinated) in the flora of settlements (Lososová et al. 2006, Knapp et al. 2008a). Lososová et al. (2006) further discuss that anemophily might benefit from a competitive advantage over entomophily due to a lack of suitable habitats for insects in urban areas.

Although the positive relationship between agricultural land use and insect pollination matches the results of Kühn et al. (2006), an explanation remains elusive as arable fields are usually species poor in general and weeds occurring there are mainly wind- or self-pollinated (Baker 1974). Interestingly, neither the main effects of urbanised area nor July temperatures were significantly related to insect pollination. How- 
ever, the interaction of both was significantly positively related. This points toward a positive urban effect that mediates the general relationship between July temperatures and the ratio of insect-pollinated neophytes, even reversing it under cooler conditions. Hence, higher or lower temperatures than the mean lead to a slight (non-linear) increase in the ratio of insect-pollinated neophytes. The mediating effect of urbanisation might be explained by a lower habitat availability of insect-pollinated species while the positive effect in cooler regions might especially be due to the urban heat island effect.

Self-pollination is associated with poor climatic conditions and unpredictable environments (Baker 1955), and is often explained as a strategy of reproduction in the absence of pollinators or mates (Kalisz et al. 2004), for example, occurring towards the edge of the geographic range of a species (Crawley 1997). Besides, alien species are more frequently self-pollinated than natives (Klotz et al. 2002). Hence, one would expect a higher frequency of selfing in urban areas and in large river valleys, as both landscapes are known to harbour a relatively high proportion of alien plants (Deutschewitz et al. 2003, Kühn et al. 2004, 2006). Our model, however, only revealed a significant (positive) response of selfing to rivers. Urbanised area remained insignificant as a predictor. Hence, it seems that, in urban regions, this reassurance option is not needed. On the contrary, there is increasing evidence that anthropogenic disturbance can negatively affect outcrossing and hence promote selfing (Eckert et al. 2009). Although the effect of temperature on selfing differed significantly between less and more urbanised areas, the difference was very small and difficult to explain.

\section{Growth form}

As expected, climatic variables were most important for explaining the ratio of all of the four growth forms in the model. Furthermore, we detected an urban effect on agriculture for annual and perennial herbs and urban effects of three predictors for woody plants. The annual temperature range is often used as a rough proxy for two important climate types in Europe. While a small temperature range characterises oceanic climate, a wide range indicates a continental climate (Driscoll and Yee Fong 1992). According to our results, annual temperature range was a significant variable that explained ratio changes in all four growth forms. The ratio of annuals decreased with the increasing influence of continental climate.

Annuals are often associated with arable fields, as fields are disturbed relatively regularly (Lososová et al. 2006) and offer a large number of microsites, which are fundamental for the establishment of annuals. However, our results do not support this assumption, as agriculture was not significant as a main effect. This might be because very few of the neophytes are species that are associated with agriculture (Klotz et al. 2002). Highly urbanised areas harbour a high ratio of annuals in absence of agricultural land and a small ratio of annuals in presence of agricultural land. On the other hand, in areas with a high proportion of agricultural land, an additional high proportion of urban 
area leads to a decrease in the ratio of annuals. Hence, it seems that neophytes cannot cope with two strong types of disturbance simultaneously. The occurrence of two different types of disturbance at the same time might be too strong in magnitude and/or frequency, hinting towards the "intermediate disturbance hypothesis" (Huston 1979).

As in previous studies (Chocholoušková and Pyšek 2003, Lososová et al. 2006, Knapp et al. 2008a), we detected an increase in the ratio of biennials with an increase in urbanised area. Lososová et al. (2006) ascribe this pattern to the existence of socalled mosaics of early to mid-successional stages in cities that offer habitats to all lifespan categories. We did not find any significant interactions that explained the ratio of biennials. One might argue that urban areas simply offer more favourable (or less unfavourable) conditions for biennial neophytes (see the positive relationship with UrbanArea). It might also simply be that there is no interaction due to the low number of biennials per grid cell, i.e. a low overall variability.

Our results revealed a large ratio of perennial herbs in more urbanised areas if the proportion of agricultural area was small. In contrast, increasing agricultural area led to a much smaller share of perennial herbs in highly urbanised areas. A possible reason for this could be that the large majority of the neophytes in Germany are intentionally introduced ornamental plants (Lambdon et al. 2008) rather than neophytes that colonize agricultural fields.

Although we did not find that urbanised area had a significant main effect on woody neophytes, our results revealed differences in the rural-urban gradient for three variables. A potential explanation for the benefit that trees and shrubs experience from increased summer precipitation could be deduced from the trade-off between shadeand drought-tolerance. As adaptions of shade-tolerant species preclude a tolerance to drought conditions, they would benefit from moister soils caused by increased summer rainfall (Smith and Huston 1989). This could also perhaps explain the outcome that the positive effect of increased summer precipitation on woody plants is even greater in urban areas. This is because urban areas tend to be even warmer and drier, hence the dependency of shade-tolerant plants on water is even increased. However, we can only speculate about this, as woody plants are not shade-tolerant in general and we did not include the functional types associated with tolerance to shade or drought, neither for trees nor shrubs, in our analysis.

In areas with the lowest rates of urbanisation, an increasing number of geological patches (i.e. coherent areas of the same geological type) had a slightly positive effect. This is probably related to habitat heterogeneity and is in line with the findings of Kühn et al. (2004). Towards the urban end of the gradient, however, this relation is firstly flattened and then even changes direction. Hence, in less heterogeneous regions, urbanisation promotes shrubs and trees again. Most of them, though, are ornamental species that are planted in parks and gardens (Hanspach et al. 2008). Hence, these species are easily promoted by urbanisation. Admittedly, at the moment no reasonable explanation can be given for the changing effect of the area of limestone in conjunction with increasing urbanised area. 


\section{Diaspore mass}

While four of six studies that were examined by Williams et al. (2015) reported an increase in species with heavier seeds in urban areas, the results of Kalusová et al. (2017) suggest the opposite.

Our results revealed a great number of variables that explain the mass of diaspores. As already encountered by Salisbury (1942), species with larger seeds are more frequent in habitats with higher temperatures. More recently these findings were corroborated by Murray et al. (2004). This relationship between larger seeds and higher temperatures is often explained by the better competitive performance of larger seeds over smaller seeds under poor or stressful conditions such as nutrient deficiency (Westoby et al. 1996), shade (e.g. Leishman and Westoby 1994, Grubb and Metcalfe 1996), and drought (Hendrix et al. 1991).

It is known that seed mass is positively correlated with growth form or adult longevity (Salisbury 1942, Baker 1972, Thompson and Rabinowitz 1989). Thus, annual herbs have smaller seeds than perennial herbs, which again have smaller seeds than shrubs and trees (e.g. Westoby et al. 1996). Several mechanisms generate this pattern. Firstly, due to mechanical constraints, small and short-lived species are not able to produce large seeds. Secondly, when released from the same height, lighter seeds travel further than heavier seeds of similar morphology. As heavy seeds would lead to difficulties of dispersal, small plants tend to produce lighter seeds (Rees 1997).

We showed that urbanised area itself is negatively related to the diaspore mass of neophytes. This matches the results of Kalusová et al. (2017) but contradicts the papers which were reviewed by Williams et al. (2015). Williams et al. argue that heavier seeds are better adapted to hazardous conditions (e.g. drought, competition, deep shade or burial) which are often present in cities. Baker (1972) reported that larger seeds are favoured in arid areas since they provide sufficient resources for the seedling. Our results partly support this suggestion; however, they also point out that large seeds benefit from wet but urban conditions. One might suggest that in rather dry conditions additional precipitation can provide sufficient water to allow photosynthesis for carbon allocation into large seeds.

Most interesting is that the interaction of urban land use amplifies the effect of climatic variables but dampens that of geological conditions. This is a hint towards homogenisation of geological subsoils (Groffman et al. 2014), for example, due to translocation of soil material and bedrock. Extremes in climatic conditions are thus amplified, for example, by changing the physical conditions of the environment (Heisler and Brazel 2010) or by promoting an urban effect on trait compositions.

\section{Flowering phenology}

Phenology - the timing of biological events - is known to be linked to climate change. Change in climate leads to change in phenology. Despite climate, changes of further environmental conditions (e.g. land use change) can also lead to shifts in timing (Cara- 
Donna et al. 2014). Our models revealed multiple climatic, geological and land-cover variables that explain shifts in the timing of the first flowering. CaraDonna et al. (2014) detected advanced first flowering with increased temperatures over time in the same plot and so we expected higher temperatures that would lead to advanced first flowering over geographical space.

However, our results denote a slight delay with higher July temperatures and even more delay in more urbanised areas with high July temperatures. It is well known that many urban neophytes tend to flower late in the year (Celesti-Grapow et al. 2003, Knapp and Kühn 2012). Hence, it is likely that human preference selected for lateflowering species (i.e. to have colourful gardens when native flowers are already in decay) promote the observed pattern.

The earlier onset of flowering in forests and agricultural areas can be explained by the increasing dominance of trees and cultivated crops in the course of the year. Except for a few tree species and cultivated species, this especially promotes early flowering plants (i.e. before canopy cover closes or crops begin competing for light). We understand the even amplified effect in more urban areas to be a result of the urban heat island effect. Hence, city forests are relatively warmer compared to forests that are distant to cities and, therefore, they lead to an even earlier closure of the canopy and hence to an even earlier onset of flowering. The same applies for arable fields close to cities.

Lastly, there is a common pattern in most observed interactions: Urbanisation leads to later flowering, probably for the reasons discussed above (human preference for late flowering species; most neophytes are introduced for ornamental reasons Lambdon et al. 2008). Further, late flowering occurs with additional heterogeneity, either the number of geological substrate patches, specific substrates such as sand, or infrastructure such as roads. Again, this might be a confounding effect of sampling from an available species pool: all these additional structures promote species richness. In general, neophytes tend to flower later. Increasing species richness hence increases the probability of drawing a late flowering species from the available species pool of neophytes.

\section{Synthesis}

Across all traits, precipitation and temperature were usually the most important predictors as a main effect. In most interaction terms, however, other predictors were included. The functional response of alien species is therefore reliant on climatic variables being independent from urbanisation (e.g. the urban heat island effect). This contrasts with the results of Kühn et al. (2017) for species richness along the rural-urban gradient, for which the length of roads and railroads were important predictors. There is a main difference between a functional and a taxonomic perspective on plant invasion patterns in the rural-urban gradient. While species richness is largely determined by propagule and colonisation pressure (Pyšek et al. 2015), functional traits seem to respond more closely to physiological constraints imposed by climate (Woodward and Williams 1987). There were significant interactions with urbanisation for almost any 
trait but with varying predictors, suggesting that there is an 'urban effect', however much smaller than purely climatic effects. And in addition, an idiosyncratic effect of traits was visible in our study. We therefore argue that the main responses of the studied traits refer to the physiological constraints of climate, but their interactions are rather dependent on the context (Kueffer et al. 2013), i.e. the specific species with their specific environmental preferences at their specific stage of the invasion process being mediated by traits.

\section{Conclusions}

We aimed to extend the approach of Kühn et al. (2017) in order to identify changes in the response of traits of neophytes to environmental conditions along the ruralurban gradient. While they did not find conditions that determine neophyte richness in general, being fundamentally different in cities compared to rural areas, we show that considering functional plant traits allows more explicit and more differentiated insights. By modelling the plant traits of neophytes, instead of their richness or their proportion, we could reveal substantial differences between urban and rural environments. In addition, we found a more complex effect of urbanisation in many of the responses of the traits to environmental conditions, suggesting that different ecological processes act within cities compared to rural areas. These differences can mainly be traced back to interferences and alterations that are related to urban development and human activity in general. To enhance our understanding of functional ecological mechanisms in cities, it is not only important to describe how urbanisation affects species composition in relation to species origin, but also to scrutinise the different processes behind these patterns. We argue that studying plant traits is an appropriate way to do so and suggest considering plant traits more explicitly in studies of urban ecology.

\section{Acknowledgements}

FLORKART (http://www.floraweb.de) contains records of thousands of volunteers and is maintained by the Federal Agency for Nature Conservation (Bundesamt für Naturschutz, BfN) on behalf of the German Network for Phytodiversity (NetPhyD). We thank Laura Celesti-Grapow and another anonymous reviewer for helpful comments on the manuscript. Further, we would like to thank Owen Lyons for improving the linguistic quality of previous versions of the manuscript. Dagmar Haase's research was carried out with support from the project ENABLE (http://projectenable.eu), funded through the 2015-2016 BiodivERsA COFUND call, nationally funded by the German Ministry for Education and Research (BMBF). 


\section{References}

Aitchison J (1986) The Statistical Analysis of Compositional Data. Chapman and Hall, London, 416 pp. https://doi.org/10.1002/bimj.4710300705

Baker HG (1955) Self-compatibility and establishment after 'long-distance' dispersal. Evolution 9: 347-349. https://doi.org/10.1111/j.1558-5646.1955.tb01544.x

Baker HG (1972) Seed weight in relation to environmental conditions in California. Ecology 53: 997-1010. https://doi.org/10.2307/1935413

Baker HG (1974) The evolution of weeds. Annual review of Ecology and Systematics 5: 1-24. https://doi.org/10.1146/annurev.es.05.110174.000245

Billheimer D, Guttorp P, Fagan WF (2001) Statistical interpretation of species composition. Journal of the American Statistical Association 96: 1205-1214. https://doi. org/10.1198/016214501753381850

Bjørnstad ON (2013) ncf: Spatial nonparametric covariance functions. R package ver. 1:1-5.

Borcard D, Legendre P, Drapeau P (1992) Partialling out the spatial component of ecological variation. Ecology 73(3): 1045-1055. https://doi.org/10.2307/1940179

Bowler DE, BuyungAli L, Knight TM, Pullin AS (2010) Urban greening to cool towns and cities: A systematic review of the empirical evidence. Landscape and Urban Planning 97: 147-155. https://doi.org/10.1016/j.landurbplan.2010.05.006

Bridgman H, Warner R, Dodson J (1995) Urban Biophysical Environments. Oxford University Press, Melbourne, 152 pp.

Bundesamt für Kartographie und Geodäsie (2012) Landbedeckungsmodell Deutschland 2012 (LBM-DE2012). http://www.bkg.bund.de

Bundesanstalt für Geowissenschaften und Rohstoffe (1993) Geologische Karte der Bundesrepublik Deutschland 1:1.000 000. Bundesanstalt für Geowissenschaften und Rohstoffe, Hannover.

CaraDonna PJ, Iler AM, Inouye DW (2014) Shifts in flowering phenology reshape a subalpine plant community. Proceedings of the National Academy of Sciences of the United States of America 111(13): 4916-4921. https://doi.org/10.1073/pnas.1323073111

Celesti-Grapow L, Di Marzio P, Blasi C (2003) Temporal niche separation of the alien flora of Rome. In: Child L, Brock JH, Brundu G, Prach K, Pyšek P, Wade M, Williamson M (Eds) Plant Invasions: Ecological Threats and Management Solutions. Backhuys Leiden, Kerkwerve, 101-111.

Chocholoušková Z, Pyšek P (2003) Changes in composition and structure of urban flora over 120 years: a case study of the city of Plzen. Flora 198: 366-376. https://doi. org/10.1078/0367-2530-00109

Connor EF, Hafernik J, Levy J, Moore VL, Rickman JK (2002) Insect conservation in an urban biodiversity hotspot: The San Francisco Bay area. Journal of Insect Conservation 6: 247-259. https://doi.org/10.1023/A:1024426727504

Crase B, Liedloff AC, Wintle BA (2012) A new method for dealing with residual spatial autocorrelation in species distribution models. Ecography 35: 879-888. https://doi. org/10.1111/j.1600-0587.2011.07138.x 
Crawley MJ (1997) Chapter 6: Sex. In: Crawley MJ (Ed.) Plant Ecology. Blackwell Science Ltd., 156-213. https://doi.org/10.1002/9781444313642.ch6

Crawley MJ (2012) The R Book ( $2^{\text {nd }}$ ed). Wiley and Sons Ltd., West Sussex, 1051 pp. https:// doi.org/10.1002/9781118448908

Deutschewitz K, Lausch A, Kühn I, Klotz S (2003) Native and alien plant species richness in relation to spatial heterogeneity on a regional scale in Germany. Global Ecology and Biogeography 12: 299-311. https://doi.org/10.1046/j.1466-822X.2003.00025.x

Didham RK, Tylianakis JM, Hutchison MA, Ewers RM, Gemmell NJ (2005) Are invasive species the drivers of ecological change? Trends in Ecology and Evolution 20: 470-474. https://doi.org/10.1890/04-0669

Digby PSB (1958) Flight activity in the blowfly, Calliphora erythrocephala, in relation to wind speed, with special reference to adaptation. Journal of Experimental Biology 35: 776-795.

Dormann CF (2007) Assessing the validity of autologistic regression. Ecological Modelling 207: 234-242. https://doi.org/10.1016/j.ecolmodel.2007.05.002

Dormann CF, Elithh J, Bacher S, Buchmann C, Carl G, Carré G, Marquéz JRG, Gruber B, Lafourcade B, Leitão PJ, Münkemüller T, McClean C, Osborne PE, Reineking B, Schroder B, Skidmore AK, Zurell D, Lautenbach S (2013) Collinearity: A review of methods to deal with it and a simulation study evaluating their performance. Ecography 36: 27-46. https:// doi.org/10.1111/j.1600-0587.2012.07348.x

Douglas I, James P (2015) Urban Ecology. An Introduction. Routledge, Abingdon, 500 pp.

Driscoll DM, Yee Fong JM (1992) Continentality: A basic climatic parameter re-examined. International Journal of Climatology 12: 185-192. https://doi.org/10.1002/joc.3370120207

Eckert CG, Kalisz S, Geber MA, Sargent R, Elle E, Cheptou P-O, Goodwillie C, Johnston OJ, Kelly JK, Moeller DA, Porcher E, Ree RH, Vallejo-Marín M, Winn AA (2009) Plant mating systems in changing world. Trends in Ecology and Evolution 25(1): 35-43. https://doi. org/10.1016/j.tree.2009.06.013

Elton CS (1958) The Ecology of Invasions by Animals and Plants. Methuen, London,181 pp. https://doi.org/10.1007/978-1-4899-7214-9

Essl F, Bacher S, Blackburn TM, Booy O, Brundu B, Brunel S, Cardoso A-C, Eschen R, Gallardo B, Galil B (2015) Crossing frontiers in tackling pathways of biological invasions. BioScience 65: 769-782. https://doi.org/10.1093/biosci/biv082

ESRI (2016) ArcGIS Desktop. Ver. 10.5. Environmental Systems Research Institute, Redlands.

Fischer LK, von der Lippe M, Kowarik I (2013) Urban grassland restoration: which plant traits make desired species successful colonizers? Applied Vegetation Science 16: 272-285. https://doi.org/10.1111/j.1654-109X.2012.01216.x

Forman RTT (2014) Urban Ecology - Science of Cities. Cambridge University Press, Cambridge, $476 \mathrm{pp}$.

Fronzek S, Carter TR, Jylhä K (2012) Representing two centuries of past and future climate for assessing risks to biodiversity in Europe. Global Ecology and Biogeography 21: 19-35. https://doi.org/10.1111/j.1466-8238.2011.00695.x

Garnier E, Stahl U, Laporte M-A, Kattge J, Mougenot I, Kühn I, Laporte B, Amiaud B, Ahrestani FS, Bönisch G, Bunker DE, Cornelissen JHC, Díaz S, Enquist BJ, Gachet S, Jaureguiberry P, Kleyer M, Lavorel S, Maicher L, Pérez-Harguindeguy N, Poorter H, Schil- 
dhauer M, Shipley B, Violle C, Weiher E, Wirth C, Wright IJ, Klotz S (2017) Towards a thesaurus of plant characteristics: an ecological contribution. Journal of Ecology 105: 298-309. doi: 10.1111/1365-2745.12698

Groffman PM, Cavender-Bares J, Bettez ND, Grove JM, Hall SJ, Heffernan JB, Hobbie SE, Larson KL, Morse JL, Neill C, Nelson K, O'Neil-Dunne J, Ogden L, Pataki DE, Polsky C, Chowdhury RR, Steele MK (2014) Ecological homogenization of urban USA. Frontiers in Ecology and the Environment 12: 74-81. https://doi.org/10.1890/120374

Grubb P, Metcalfe D (1996) Adaption and inertia in the Australian tropical lowland rainforest flora: contradictory trends in intergeneric and intrageneric comparison of seed size in relation to light demand. Functional Ecology 10: 512-520. https://doi.org/10.2307/2389944

Guisan A, Zimmermann NE (2000) Predictive habitat distribution models in ecology. Ecological Modelling 135: 147-186. https://doi.org/10.1016/S0304-3800(00)00354-9

Hanspach J, Kühn I, Pyšek P, Boos E, Klotz S (2008) Correlates of naturalization and occupancy of introduced ornamentals in Germany. Perspectives in Plant Ecology, Evolution and Systematics 10: 241-250. https://doi.org/10.1016/j.ppees.2008.05.001

Heisler GM, Brazel AJ (2010) The Urban Physical Environment: Temperature and Urban Heat Islands. In: Aitkenhead-Peterson J, Volder A (Eds) Urban Ecosystem Ecology. Agronomy Monograph 55, Madison, 29-56.

Hendrix SD, Nielsen E, Nielsen T, Schutt M (1991) Are seedlings from small seeds always inferior to seedlings from large seeds? Effects of seed biomass on seedling growth in Pastinaca sativa L. The New Phytologist 119(2): 299-305. https://doi.org/10.1111/j.1469-8137.1991. tb01034.x

Hijmans RJ, van Etten J, Cheng J, Mattiuzzi M, Sumner M, Greenberg JA, Lamigueiro OP, Bevan A, Racine EB, Shortridge A (2016) raster: Geographic Data Analysis and Modelling. R package version: $2.5-8$.

Huston MA (1979) A general hypothesis of species diversity. American Naturalist 113: 81101. https://doi.org/10.1086/283366

IPBES (2019) Global assessment report on biodiversity and ecosystem services of the Intergovernmental Science-Policy Platform on Biodiversity and Ecosystem Services.

Jehlík V, Dostálek J, Frantík T (2019) Alien plants in Central European river ports. NEOBIOTA 45: 93-115. https://doi.org/10.3897/neobiota.45.33866

Kalisz S, Vogler DW, Hanley KM (2004) Context-dependent autonomous self-fertilization yields reproductive assurance and mixed mating. Nature 430: 884-887. https:/doi. org/10.1038/nature02776

Kalusová V, Čeplová N, Lososová Z (2017) Which traits influence the frequency of plant species occurrence in urban habitat types? Urban Ecosystems 20: 65-75. https://doi.org/10.1007/ s11252-016-0588-3

Klotz S, Kühn I, Durka W (2002) BIOLFLOR: Eine Datenbank mit biologisch-ökologischen Merkmalen zur Flora von Deutschland. Schriftreihe der Vegetationskunde 38. Bundesamt für Naturschutz, Bonn, 334 pp.

Knapp S, Kühn I (2012) Origin matters: widely distributed native and non-native species benefit from different functional traits. Ecology Letters 15: 696-703. https://doi.org/10.1111/ j.1461-0248.2012.01787.x 
Knapp S, Kühn I, Schweiger O, Klotz S (2008a) Challenging urban species diversity: contrasting phylogenetic patterns across plant functional groups in Germany. Ecology Letters 11: 1054-1064. https://doi.org/10.1111/j.1461-0248.2008.01217.x

Knapp S, Kühn I, Wittig R, Ozinga WA, Poschlod P, Klotz S (2008b) Urbanization causes shifts in species' trait state frequencies. Preslia 80: 375-388.

Knapp S, Kühn I, Stolle J, Klotz S (2010) Changes in the functional composition of a Central European urban flora over three centuries. Perspectives in Plant Ecology Evolution and Systematics 12: 235-244. https://doi.org/10.1016/j.ppees.2009.11.001

Kowarik I (1990) Some responses of flora and vegetation to urbanization in Central Europe. In: Sukopp H, Hejni S, Kowarik I (Eds) Urban Ecology. SPB Academic Publishing, The Hague, 5-74.

Kueffer C, Pyšek P, Richardson DM (2013) Integrative invasion science: model systems, multisite studies, focused meta-analysis and invasion syndromes. New Phytologist 200: 615633. doi: 10.1111/nph.12415

Kühn I, Bierman SM, Durka W, Klotz S (2006) Relating geographical variation in pollination types to environmental and spatial factors using novel statistical methods. New Phytologist 172: 127-139. https://doi.org/10.1111/j.1469-8137.2006.01811.x

Kühn I, Brandl R, Klotz S (2004) The Flora of German cities is naturally species rich. Evolutionary Ecology Research 6: 749-764.

Kühn I, Wolf J, Schneider A (2017) Is there an urban effect in alien plant invasions? Biological Invasions 19: 3505-3513. https://doi.org/10.1007/s10530-017-1591-1

Lambdon PW, Pyšek P, Basnou C, Hejda M, Arianoutsou M, Essl F, Jarosik V, Pergl J, Winter M, Anastasiu P, Andriopoulos P, Bazos I, Brundu G, Celesti-Grapow L, Chassot P, Delipetrou P, Josefsson M, Kark S, Klotz S, Kokkoris Y, Kühn I, Marchante H, Perglova I, Pino J, Vilà M, Zikos A, Roy D, Hulme PE (2008) Alien flora of Europe: species diversity, temporal trends, geographical patterns and research needs. Preslia 80: 101-149. https:// doi.org/10261/61126

Leishman MR, Westoby M (1994) The role of large seed size in shaded conditions: experimental evidence. Functional Ecology 8: 205-214. https://doi.org/10.2307/2389903

Lososová Z, Chytrý M, Kühn I, Hájek O, Horáková V, Pyšek P, Tichý L (2006) Patterns of plant traits in annual vegetation of man-made habitats in central Europe. Perspectives in Plant Ecology, Evolution and Systematics 8: 69-81. https://doi.org/10.1016/j. ppees.2006.07.001

Lososová Z, Chytrý M, Tichý L, Danihelka J, Fajmon K, Hájek O, Kintrová K, Kühn I, Láníková D, Otýpková Z, Řehořek V (2012) Native and alien floras in urban habitats: a comparison across 32 cities of central Europe. Global Ecology and Biogeography 21: 545-555. https://doi.org/10.1111/j.1466-8238.2011.00704.x

MacDougall AS, Turkington R (2005) Are invasive species the drivers or passengers of change in degraded ecosystems? Ecology 86: 42-55. https://doi.org/10.1890/04-0669

Manceur AM, Kühn I (2014) Inferring model-based probability of occurrence from preferentially sampled data with uncertain absences using expert knowledge. Methods in Ecology and Evolution 5: 739-750. https://doi.org/10.1111/2041-210X.12224 
McGill BJ, Enquist BJ, Weiher E, Westoby M (2006) Rebuilding community ecology from functional traits. Trends in Ecology \& Evolution 21: 178-185. https://doi.org/10.1016/j. tree.2006.02.002

Menzel A, Hempel S, Manceur AM, Götzenberger L, Moora M, Rillig MC, Zobel M, Kühn I (2016) Distribution patterns of arbuscular mycorrhizal and non-mycorrhizal plant species in Germany. Perspectives in Plant Ecology, Evolution and Systematics 21: 78-88. https:// doi.org/10.1016/j.ppees.2016.06.002

Meyer SE, Carlson SL (2001) Achene mass variation in Ericameria nauseosus (Asteraceae) in relation to dispersal ability and seedling fitness. Functional Ecology 15: 274-281. https:// doi.org/10.1046/j.1365-2435.2001.00520.x

Murray BR, Brown AHD, Dickman CR, Crowther MS (2004) Geographical gradients in seed mass in relation to climate. Journal of Biogeography 31(3): 379-388. https://doi. org/10.1046/j.0305-0270.2003.00993.x

Netzwerk Phytodiversität Deutschlands e.V. (NetPhyD) und Bundesamt für Naturschutz (BfN) (2013) Verbreitungsatlas der Farn- und Blütenpflanzen Deutschlands. Bundesamt für Naturschutz, Bonn, 912 pp.

Nowak DJ, Stein SM, Randler PB, Greenfiel EJ, Comas SJ, Carn MA, Alig RJ (2010) Sustaining America's urban trees and forests. US Forest Service General Technical Report. NRS 62: 1-28. https://doi.org/10.2737/NRS-GTR-62

Oke TR (1982) The energetic basis of the heat island. Quarterly Journal of the Royal Meteorological Society 108: 1-24. https://doi.org/10.1002/qj.49710845502

OpenStreeMap.org and MapCruzin.com (Undated) Shapefile Map Layers of German Roads and Railways. Derived from the Open Street Map Project and provided by MapCruzin. https://mapcruzin.com/free-germany-arcgis-maps-shapefiles.htm

Pebesma E, Bivand R, Rowlingson B, Rubio VG, Sumner M, MacQueen D, Lemon J, O'Brien J (2017) sp: Classes and Methods for Spatial Data. R package version: 1.2-5.

Pyšek P, Richardson DM, Rejmánek M, Webster GL, Williamson M, Kirschner J (2004) Alien plants in checklists and floras: towards better communication between taxonomists and ecologists. Taxon 53: 131-143. https://doi.org/10.2307/4135498

Pyšek P, Manceur AM, Alba C, McGregor KF, Pergl J, Štajerová K, Chytrý M, Danihelka J, Kartesz J, Klimešová J, Lučanová M, Moravcová L, Nishino M, Sádlo J, Suda J, Tichý L, Kühn I (2015) Naturalization of central European plants in North America: species traits, habitats, propagule pressure, residence time. Ecology 96: 762-774. https://doi. org/10.1890/14-1005.1

QGIS Development Team (2015) QGIS Desktop. Version 2.18. Open Source Geospatial Foundation, Delaware.

R Core Team (2017) R: A language and environment for statistical computing. R Foundation for Statistical Computing, Vienna.

Raunkiær C (1934) The Life Forms of Plants and Statistical Plant Geography. Oxford University Press, Oxford, 632 pp.

Rees M (1997) Chapter 7: Seed Dormancy. In: Crawley MJ (Ed.) Plant Ecology. Blackwell Science Ltd., 214-238. https://doi.org/10.1002/9781444313642.ch7 
Salisbury EJ (1942) The Reproductive Capacity of Plants. G Bell and Sons, London, 244 pp.

Seebens H (2019) Invasion Ecology: Expanding Trade and the Dispersal of Alien Species. Current Biology 29: R120-R122. https://doi.org/10.1016/j.cub.2018.12.047

Smith CC, Fretwell S (1974) The optimal balance between size and number of offspring. American Naturalist 108: 499-506. https://doi.org/10.1086/282929

Smith T, Huston M (1989) A theory of the spatial and temporal dynamics of plant-communities. Vegetatio 83: 49-69. https://doi.org/10.1007/978-94-009-1934-1_5

Sodhi NS, Koh LP, Peh KSH, Tan HTW, Chazdon RL, Corlett RT, Lee TM, Colwell RK, Brook BW, Sekercioglu CH, Bradshaw CJA (2008) Correlates of extinction proneness in tropical angiosperms. Diversity and Distributions 14: 1-10. https://doi.org/10.1111/ j.1472-4642.2007.00398.x

Sukopp H, Werner P (1983) Urban environment and vegetation. In: Holzner W, Werger MJA, Ikusima I (Eds) Mans's impact on vegetation. Dr. W. Junk Publisher (The Hague): $247-$ 260. https://doi.org/10.1007/978-94-009-7269-8_19

Thompson K, Rabinowitz D (1989) Do big plants have big seeds? American Naturalist 133: 722-728. https://doi.org/10.1086/284947

United Nations (2014) World Urbanization Prospects: The 2014 Revision Population Database. http://www.es.a.un.org/unup/

Van Swaay CAM, Plate CL, Van Strien A (2002) Monitoring butterflies in the Netherlands: how to get unbiased indices. Proceedings of the Section Experimental and Applied Entomology of the Netherlands Entomological Society 13: 21-27.

Vitousek PM, Mooney HA, Lubchenco J, Melillo JM (1997) Human domination of Earth's ecosystems. Science 277: 494-499. https://doi.org/10.1126/science.277.5325.494

Von der Lippe M, Kowarik I (2008) Do cities export biodiversity? Traffic as dispersal vector across urban-rural gradients. Diversity and Distributions 14: 18-25. https://doi. org/10.1111/j.1472-4642.2007.00401.x

Westoby M, Leishman M, Lord J (1996) Comparative ecology of seed size and dispersal. Philosophical Transactions of The Royal Society B. Biological Sciences 351: 1309-1318. https:// doi.org/10.1098/rstb.1996.0114

Whitehead DR (1968) Wind pollination in the angiosperms: evolutionary and environmental considerations. Evolution 23: 28-35. https://doi.org/10.1111/j.1558-5646.1969. tb03490.x

Williams NSG, Hahs AK, Vesk PA (2015) Urbanisation, plant traits and the composition of urban floras. Perspectives in Plant Ecology 17: 78-86. https://doi.org/10.1016/j. ppees.2014.10.002

Woodward FI, Williams BG (1987) Climate and plant distribution at global and local scales. Vegetatio 69: 189-197. https://doi.org/10.1007/BF00038700

Wright K (2017) corrgram: Plot a Correlogram. R package version: 1.12.

Yee TW (2015) Vector Generalized Linear and Additive Models: With an Implementation in R. Springer (New York): 1-589. https://doi.org/10.1007/978-1-4939-2818-7_19

Yee TW (2017) VGAM: Vector Generalized Linear and Additive Models. R package version: $1.0-4$. 


\section{Supplementary material I}

\section{Supplementary tables}

Authors: Janis Wolf, Dagmar Haase, Ingolf Kühn

Data type: (measurement/occurrence/multimedia/etc.)

Explanation note: Table S1: List of neophyte species included in the study with information on the number of grid cells they occured, how frequently they occured in the 2599 grid cells, pollination type, growth form, diaspore mass and beginning month of flowering. Table S2: Overview on minimum, maximum, median and/or mean values across 2599 grid cells in Germany.

Copyright notice: This dataset is made available under the Open Database License (http://opendatacommons.org/licenses/odbl/1.0/). The Open Database License $(\mathrm{ODbL})$ is a license agreement intended to allow users to freely share, modify, and use this Dataset while maintaining this same freedom for others, provided that the original source and author(s) are credited.

Link: https://doi.org/10.3897/neobiota.544.38898.suppl1 